\title{
INFLUENCES FOR CHANGE IN THE DENTAL HEALTH STATUS OF POPULATIONS: AN HISTORICAL PERSPECTIVE
}

\author{
Brian A. Burt, BDSc, MPH, PhD*
}

Epidemiologists often use mortality statistics to examine trends in health and disease, ${ }^{89}$ principally because these data are frequently all that are available, and also because they are reasonably reliable. ${ }^{69} \mathrm{~A}$ major drawback to their use, however, is that mortality statistics are an extremely crude measure of health status, for they say nothing about the quality or degree of illness and disability in a population.

The dental epidemiologist's equivalent of mortality statistics is data on the loss of teeth. Until recently, these data, too, were frequently the only existing dental statistics. Tooth mortality data are a crude measure of dental health, but they also can probably be compared over time with reasonable confidence.

This paper attempts to find reasons for any changes in dental health status over the last 50-100 years. Scarcity of data requires that tooth retention be used as a measure of dental health, despite its inadequacy; it also restricts the assessment of dental disease prevalence in an historical perspective almost totally to dental caries. Another constraint is that most historical data are available only from the United States and Great Britain; it is contended, however, that the conclusions reached from these countries can be more widely applied.

Dental disease up to the 1930's

Both dental caries and periodontal disease afflicted ancient man, ${ }^{14}$ but the prevalence of caries in Britain remained low until the 18 th century. ${ }^{38}$ It then began to rise, and became highly prevalent in the second half of the 19th century.27,29 Untreated decay and missing teeth then became common, ${ }^{19}$ with caries prevalence in adults approximating that found today. ${ }^{36}$

The prevalence of caries was high in a number of countries in the early years of this century, ${ }^{83,112,113}$ and led to the development of School Dental Services in Britain and Norway before World War 1,17,85 as well as the establishment of the New Zealand School Dental Nurse plan in 1921. ${ }^{17}$ Several nationwide studies in Britain, beginning in the early 1920's, were sponsored by the Medical Research Council (MRC) to respond to concerns about the extent of dental caries, ${ }^{72}$ and to explore the relation between nutrition and caries. ${ }^{62,73,74}$ An interesting spin-off of the first of these studies, in 1922, was the determination of a lower prevalence of caries in areas which subsequently were found to be naturally fluoridated. ${ }^{1}$ Another interesting feature of this study was the use of just one examiner in order to reduce examiner variability, "... because the personal equation of each investigator might render difficult the satisfactory comparison of the results."72 Despite differences in methods of data collection and presentation, a reasonable comparison of the first MRC study and present-day conditions can be made, as shown in Table I. It seems that, among nine and 13 year olds, there are fewer unmet needs in recent years than 50 years ago, but the prevalence of caries is hardly low in the 1970s.

Dental caries was highly prevalent in the northeastern United States in the years immediately after World War $1 . .^{30,54,55}$ Thaddeus Hyatt, in a study of over 2,000

\footnotetext{
*Associate Professor of Dental Public Health, Program in Dental Public Health, School of Public Health, The University of Michigan, Ann Arbor, Michigan 48109
} 
Vol. 38, No. 4 - Fall, 1978

Table I

COMPARISON OF THE CONDITION OF SPECIFIC TEETH IN BRITISH SCHOOL CHILDREN, 1925 and 1973.

\begin{tabular}{|c|c|c|c|c|}
\hline \multirow[b]{2}{*}{ Tooth type } & \multirow[b]{2}{*}{$\underline{\text { Age }}$} & \multirow{2}{*}{$\begin{array}{l}\text { MEDICAL RESEARCH } \\
\frac{\text { COUNCIL SURVEY, } 1925}{\text { Percent carious }^{1}}\end{array}$} & \multicolumn{2}{|c|}{$\begin{array}{c}\text { NATIONAL CHILDREN'S } \\
\text { SURVEY, } 1973 \\
\end{array}$} \\
\hline & & & Percent DMF2 & Percent carious $^{3}$ \\
\hline Upper central incisors & 10 & 3 & 20 & 10 \\
\hline Upper first molars & 9 & 33 & 50 & 16 \\
\hline Upper first molars & 13 & 52 & 78 & 14 \\
\hline Lower first molars & 9 & 45 & 50 & 16 \\
\hline Lower first molars & 13 & 61.5 & 80 & 13 \\
\hline
\end{tabular}

schoolgirls in Brooklyn, ages 13-17, found that 13.5 percent of first molars and 2.5 percent of second molars were lost. ${ }^{54}$ Among adults of different ages, he found that 22-47 percent of first molars were lost. ${ }^{55}$ Hyatt suggested the prophylactic odontotomy procedure and referred to dental conditions during the military draft of World War 1 as "appalling". $55 \mathrm{He}$ estimated that there were five untreated carious lesions "in the mouth of every man, woman, and child in the United States." 55 However, that estimate was probably exaggerated, as Hyatt was projecting from conditions in the northeastern region of the United States, an area now known to have the highest caries prevalence in the country. ${ }^{91,104,105,107}$

There is little reason to doubt that caries was also highly prevalent in Scandinavia, ${ }^{92}$ Australia, and New Zealand, ${ }^{83}$ during and since the second half of the 19th century. If the writings of Wallace ${ }^{112}$ and Pickerill ${ }^{83}$ can be accepted, however, caries was practically unknown among those groups they referred to as "primitive peoples."

Dental disease from the 1930s to the present

In the United States, Brekhus examined entering freshmen students at the University of Minnesota in 1929 and 1939.12, ${ }^{13}$ He concluded that caries had increased in prevalence and intensity during the decade, though it is possible that the students in 1939 came from a higher socio-economic stratum. The series of excellent American studies in the 1930s, many of them exploring the link between fluoridated water and caries, also indicated a generally high prevalence of caries, with some regional variation. ${ }^{21,} 43,63-5,77$

A crude comparison of caries prevalence, over 40 years or so, made from different surveys of the young adults in the United States shows that caries prevalence has not changed much during that period. 12,13,27,35.43,104.107 There is evidence, however, to show that loss of permanent teeth in white children in recent years is substantially less than it was in Hagerstown 40 years ago. ${ }^{65,105,107,108}$

Figure 1 compares DMFT values for all age groups in the United States over a period of approximately 30 years. The similarity of Klein's values for children and young adults and those found in the most recent Health Examination Surveys is striking. Klein's data for adults came from what was practically the only source at that time, a study by Hollander and Dunning of employees of the Metropolitan Life Insurance Company. ${ }^{48}$ These individuals came from the area of highest caries prevalence in 
FIGURE 1

CHANGES IN DMF VALUES, UNITED STATES, 1941 to 1960-70

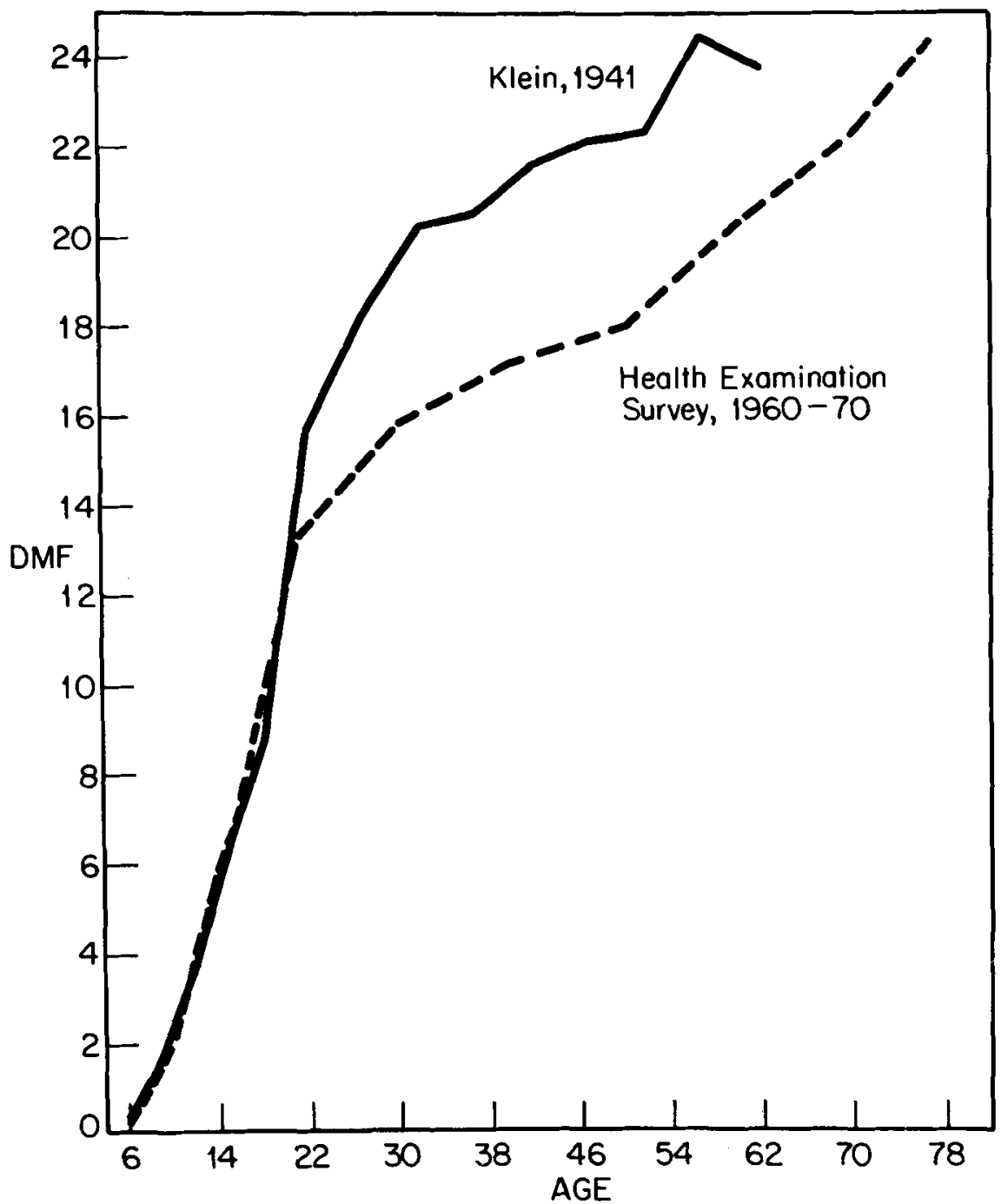

the United States. Unfortunately, the Health Examination Survey data for adults do not give regional values by age, so further comparison cannot be made.

British data also indicate that there has been little change in DMF values in young adults from early World War II to more recent times, although, as in the United States, the average number of missing teeth seems to have decreased. ${ }^{36,78}$ However, studies of several younger age-groups in Britain permit speculation on some trends in caries prevalence there. One study of a group of institutionalized children, examined in 1950 and again in 1961, concluded that caries prevalence had increased during that decade. ${ }^{58}$ Greater availability of sugar, freed from wartime rationing in 1953 , was a 
likely factor. The investigators reported that 15 -year-old children by the early 1960 s showed DMF scores of $8-10$, which is similar to current values. ${ }^{98}$ The implication is that caries prevalence may not have changed much in this age-group in Britain since about 1960 .

Turning to a younger age-group, various surveys of British five-year-olds from 1914 to 1973, done in connection with school dental service requirements show varying proportions of these children free of caries. ${ }^{75,76,79,98,113}$ However, the data show an increase in the proportion of children caries-free over the last 15 years from about 15 to 30 percent. Although no firm conclusions can be reached, the difference between 1958 and 1973 is of sufficient magnitude to pose the question of whether caries prevalence is diminishing in Britain.

Some recent evidence from Norway, 5 long recognized as an area of high caries prevalence, $, 717,92$ raises the question of whether caries prevalence in that country is also declining. Table II, for example, shows data from the school dental service in Norway from 1966 to 1976 . The trend toward reduced treatment for caries is clear, as is the marked improvement in tooth loss because of caries. Recent surveys in various districts of Norway also indicate reduced DMF values in children since 1971.5 Although these data on provided services cannot be accepted as conclusive, they too raise intriguing questions about changes in caries prevalence.

It seems safe to conclude that tooth retention in children and young adults in industrialized countries has increased in recent generations. In addition, it is possible that caries prevalence in the same countries may now be diminishing. Only time will tell whether this apparent trend is real.

Table II

SELECTED DATA FROM ANNUAL SERVICE REPORTS FROM INDIVIDUAL DISTRICTS AND COUNTIES THE PUBLIC DENTAL SERVICE, NORWAY

\begin{tabular}{|c|c|c|c|}
\hline \multirow[b]{2}{*}{ Year } & \multirow[b]{2}{*}{$\begin{array}{l}\text { No, of persons } \\
\text { seen aged } 6-17\end{array}$} & \multicolumn{2}{|c|}{$\begin{array}{l}\text { Treatment items per } 100 \\
\text { persons, permanent dentition }\end{array}$} \\
\hline & & $\begin{array}{l}\text { Teeth extracted } \\
\text { for caries }\end{array}$ & $\begin{array}{l}\text { Tooth surfaces } \\
\text { filled }\end{array}$ \\
\hline 1966 & 127,700 & 8.0 & 617.9 \\
\hline 1969 & 149,037 & 6.4 & 607.9 \\
\hline 1972 & 217,134 & 3.2 & 546.4 \\
\hline 1975 & 296,839 & 1.0 & 373.7 \\
\hline $1976^{*}$ & 325,275 & 0.7 & 340.9 \\
\hline
\end{tabular}

\section{Total tooth loss}

Figure 2 shows the proportion of edentulous adults, by age, in England and Wales, New Zealand, and the United States. ${ }^{16,36,108}$ Total loss of teeth is largely a function of the progression of dental caries and periodontal disease, though it is also related to socioeconomic status, cultural attitudes, and possibly the availability of dental care. ${ }^{36,99}$ The prevalence of edentulousness reflects, in part, the prevailing 
attitudes toward dental care. Figure 2 shows a sharp rise in edentulousness with increasing age in each country. The overall prevalence of the condition among adults in the United States, around 18 percent, ${ }^{108}$ is often attributed to inadequate recognition and treatment of periodontal disease, for periodontal disease is accepted as the greatest single cause of tooth loss after age 35.111

FIGURE 2

PROPORTION OF PERSONS EDENTULOUS, BY AGE, IN ENGLAND AND WALES, NEW ZEALAND, AND THE UNITED STATES.

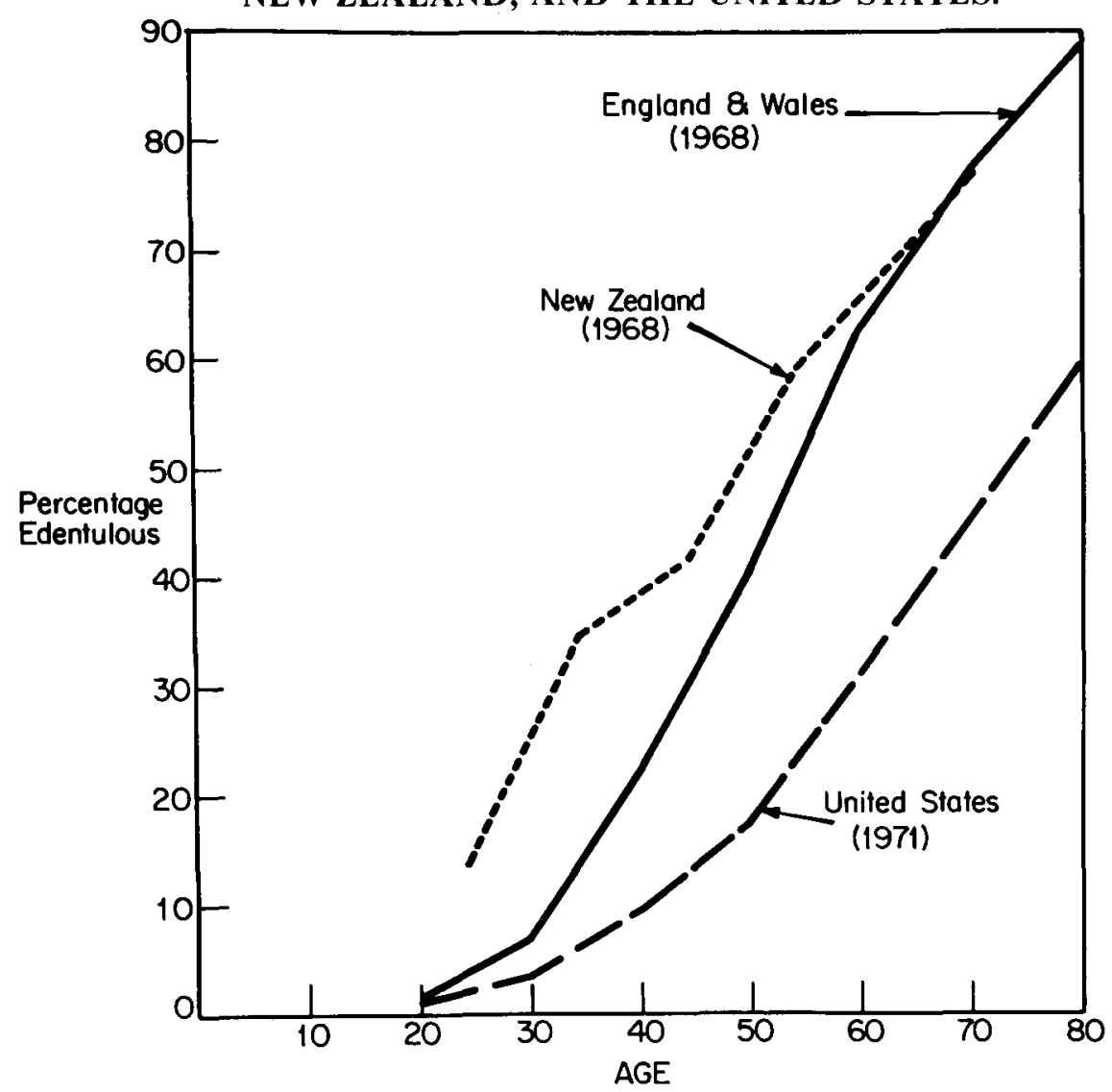

Two things should be remembered, however, in regard to the American figures on total tooth loss. One is that routine dental treatment for children is a relatively modern development. Harris ${ }^{42}$ recalls how dentistry for children was positively discouraged in the 1930's, and that signs saying "children not accepted" were freely distributed by dental suppliers. The result was undoubtedly neglected caries, which inevitably must have resulted in much tooth loss. With the emphasis now on early dental attention for children, tooth loss in youth is probably not occurring nearly as frequently as in the past. Second, and probably more important, the theory of focal infection was at its height from about 1918 to 1940 , and was still alive throughout the 
1940 's. ${ }^{25}$ In dentistry, this belief was interpreted to mean that even mildly diseased teeth could be responsible for a large number of systemic disorders, especially of the arthritic type. The result was that for a quarter of a century, countless teeth were removed in an effort to alleviate these conditions. This rationale for the removal of teeth began to be questioned in the late 1940's, and was eventually put to rest following the work of Easlick in 1951.25 But its results are still with us, and can be seen in Figure 2. Among persons 55 and older in the United States, the generation which would have received the full onslaught of this mass dental extermination, fully 51 percent are edentulous. Many of these persons lost their teeth not specifically because of dental caries or periodontal disease, but rather, because the prevailing philosophy of medical and dental practice at the time dictated that their teeth should be extracted. Today, aided by technological advances which have simplified many procedures, treatment philosophies have moved strongly toward tooth conservation and disease prevention. ${ }^{34}$ However, as edentulous people continue to influence the data for the rest of their lives, it will take about 20 years before figures show a pronounced reduction in total tooth loss in the United States.

In Britain, nearly 37 percent of the adult population is edentulous, approximately double the proportion found in the United States. The American Dental Association, in its public relations effort that it calls PEP (Public Education Program), refers to this fact as follows:

American dentistry is recognized as the world leader, and American dental health is the best in the world. In Great Britain, which is considered to have one of the better nationalized health care systems, the percentage of adults who have lost all their teeth is twice that in the United States. ${ }^{3}$

While the fact stated in the last sentence is correct, the implication that it can be attributed to the National Health Service (NHS) is not, for nearly half of edentulous British adults lost their teeth before the NHS began. ${ }^{36}$ Many more became edentulous in the first three or four years of the service, largely as a result of the backlog of neglect built up during the years of World War II, during which civilian dental services were drastically reduced. To attribute the relatively greater prevalence of total tooth loss in Britain to the effects of the delivery system under the NHS is therefore misleading. Total tooth loss in Britain is related to socioeconomic status (as it is in the United States ${ }^{108}$ ), to geographic region, and to prevailing attitudes toward dental health. ${ }^{36}$

The emergence of a preventive philosophy in the United States and the capability of being remunerated for it will likely reduce the prevalence of total tooth loss during the next generation. However, the situation in Britain is rather different; probably a preventive philosophy exists there, but present NHS practice does not make it remunerative. The delivery system under NHS encourages repair rather than prevention, ${ }^{95}$ but this philosophy probably only postpones the date of total tooth loss in many instances. ${ }^{51}$ Unless there are basic changes in the administration of the NHS, the future decline in prevalence of total tooth loss in older persons will unlikely be as pronounced in Britain as in the United States.

It can be concluded that the philosophy of dental treatment has a powerful influence on retention of teeth. The economic incentives which encourage dentists to prevent tooth loss are of greater importance than the particular delivery system under which care is provided. 


\section{Supply of manpower}

Britain has just under one dentist per 3,600 persons, a ratio nearly twice as unfavorable as the one (1:1990) now found in the United States, ${ }^{26}$ although in both countries about 50 percent of the population visit a dentist annually. ${ }^{36,109}$ Both countries have severe problems of maldistribution of dentists. In Britain, there are sharp regional differences in edentulousness, with a higher prevalence inversely proportional to the supply of dentists. ${ }^{36}$ But, as mentioned previously, attitudes toward tooth retention are also more negative in the areas of lower manpower supply. ${ }^{36}$ Regional variations in total tooth loss in the United States are much less pronounced, and a definite relation between degree of edentulessness and the regional supply of dentists cannot be detected there. Moreover, it can be seen in Figure 3 that the period of the greatest supply of dentists in the United States was around 1930, the heyday of the "focal infection" approach to dental treatment, discussed previously. It would appear that what dentists do matters more than how many there are.

\section{FIGURE 3 \\ POPULATION PER DENTIST, UNITED STATES, 1890-1975}

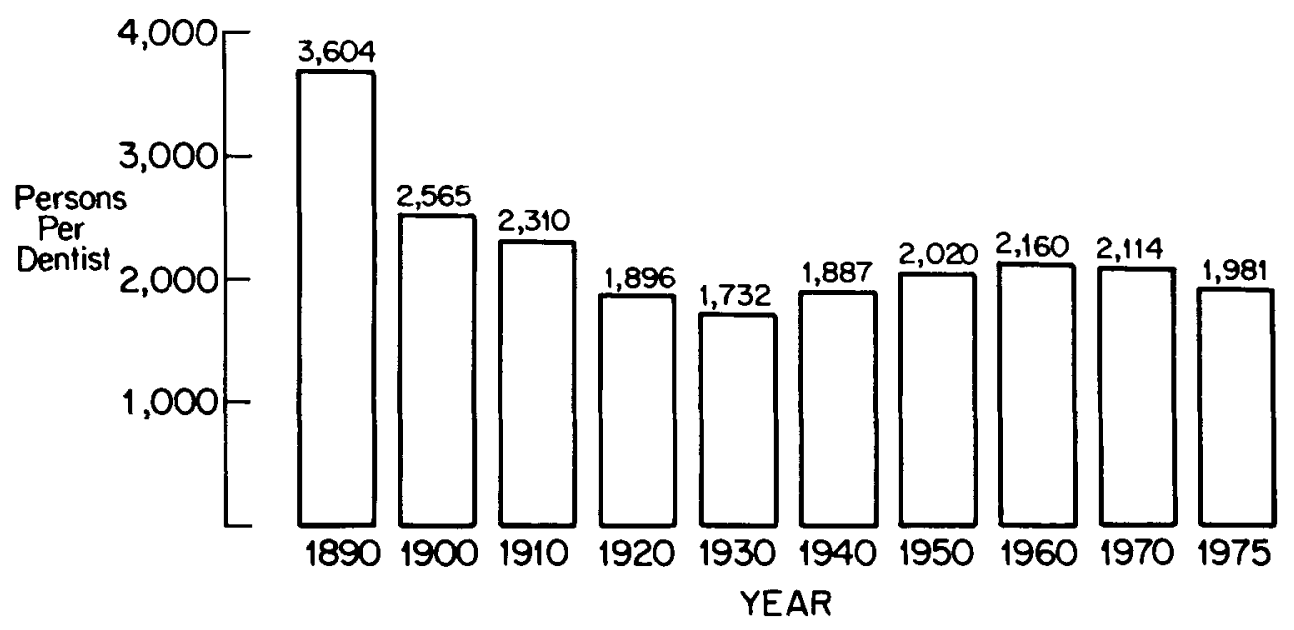

New Zealand, the third country depicted in Figure 2, provides a particularly enigmatic example of the effects of manpower supply on dental health. The total loss of teeth in younger adults there ${ }^{16}$ is considerably greater than in either Britain or the United States. And yet, New Zealand is noted for a system of dental care to schoolchildren that is frequently held up as a model, ${ }^{60}$ for despite an apparently high prevalence of caries, ${ }^{7,47}$ tooth loss in primary children in New Zealand has almost been eliminated. ${ }^{7}$ But, in 1962 , Beck $^{9}$ found a mean of 7.1 carious lesions in 15 year-olds, (only two years out of the school dental service), and 21 year-olds had lost an average of more than two teeth each. A ratio of one school dental nurse to 460 primary schoolchildren has been maintained in New Zealand for many years, ${ }^{66}$ and the dentist: adult population ratio is reasonably favorable at $1: 2300 .{ }^{26}$ How can this dichotomy of virtual elimination of tooth loss in children but a high prevalence of total 
tooth loss in adults be explained? The answer is probably cultural, for it is difficult to relate the degree of tooth loss in New Zealand adults to manpower supply.

These data from New Zealand, however, may show considerable improvement in the near future, because more than two thirds of the country is now fluoridated. ${ }^{26}$ Fewer dental nurses are required in fluoridated areas, ${ }^{22}$ and, consequently, the number of trainee dental nurses being admitted has been reduced sharply from even a few years ago. ${ }^{66}$ It can be expected that national DMF values in New Zealand children will decline in the future, as they have in fluoridated areas of the country. ${ }^{67}$ If the high prevalence of tooth loss in New Zealand is solely a result of an uncontrollably high incidence of caries, the prevalence will drop sharply but, if cultural reasons are important determinants of tooth loss, it may not. Regardless, the high degree of total tooth loss among young adults in New Zealand will continue to influence the national data for a long time.

\section{Effects of prevention}

Fluoridation has also had an effect on tooth mortality data from the United States, where some 50 percent of the population is now consuming fluoridated water, ${ }^{110}$ many of them for 15 years or more. Fluoridation is likely to be a major reason for the marked drop in tooth mortality among children, but it is doubtful whether it is totally responsible. Other aspects of what can be called a "preventive movement" must have an influence, although just how much cannot be quantified on a national basis. The widespread use of fluoride dentifrices, dietary supplements, and mouthrinses, an increased demand for dental care services by children, ${ }^{106}$ and the receipt of more preventively oriented, personal dental services ${ }^{34}$ must all be playing some role in the increased tooth retention seen among young persons in recent times. It is likely that the "preventive movement" is affecting the prevalence of periodontal disease as well as caries, but no data exist to support or disprove this suggestion.

\section{Changes in society}

Public expectations of the health care system have undoubtedly risen during the last generation; in fact, many think that there is an over-optimistic reliance on personal medical care services as a determinant of health status. ${ }^{6,33,56}$ Western societies are becoming increasingly better educated, more sophisticated, and more affluent. ${ }^{46}$ Not only has the wealth of western societies increased greatly since 1929, but incomes also are now better distributed than they were then. ${ }^{46}$ Differences among social classes in prevalence of many diseases have become less distinct. ${ }^{61}$ The result has blurred social class differences in behavior, and has tended to increase the proportion of society with a middle-class orientation. ${ }^{114} \mathrm{~A}$ major feature of the middle-class value system is "future orientation," which is associated with seeking preventive health services. ${ }^{90}$ The growth of prepaid and government-sponsored dental care plans in the United States, and of the government-type in many other countries, has increased access to dental care. When combined with growing affluence and a middle-class orientation, there has been increased desire for retention of teeth. The exact reasons why education and a middle-class background are associated with superior health status, even though the association is less distinct than it once was, ${ }^{61.89}$ have been explored by Fuchs. ${ }^{33} \mathrm{He}$ concludes that the answers are far from clear. The implications for dentistry, however, are that an increased diffusion of middle-class values in society will produce greater tooth retention in the population. 


\section{Dental health education}

At present, many think that traditional programs of dental health education, for the most part, have had negligible impact on dental health. ${ }^{32.44}$ This view has evolved from the results of studies in schools in which programs of classroom instruction have shown little or no impact on dental health or on dental health behavior of the recipients. ${ }^{84}$ The usual dependent variables in these studies have been gingival condition and amounts of dental plaque; few studies have attempted to measure the impact of programs on caries incidence. ${ }^{45,52}$

We may have become too rigid in our jud gment of educational programs. There is some evidence that traditional dental health education, when associated with a program of dental care, may have some beneficial influence on dental health, ${ }^{88}$ although accurate evaluation is difficult. Dental health education seeks to change behavior on a long-term, even, if possible, a lifetime basis. However, the practicalities of research demand that evaluation be carried out over a short period of time. The group often studied, schoolchildren, are at a stage where many are experimenting with cigarettes, alcohol and other drugs, and where they are notorious for living on junk food. Despite their intemperate behavior, some of them manage to grow into responsible adults who are able to control these earlier excesses. Perhaps much the same happens with regard to their dental health behavior. Perhaps many children who apparently are unresponsive to dental health messages at school do respond to them, at least to some degree, in later life.

We must look at the effects of dental health education over a much longer time span than we are accustomed to doing. We must consider the total impact of traditional programs, including the myriad bag of informal messages from magazine articles and TV advertisements, regardless of their quality, ${ }^{31}$ and the educational effects of the Federal Trade Commission's deliberations regarding sugar-coated breakfast cereals. ${ }^{53}$ Of course, this approach means that it is nearly impossible to state with any confidence what effect dental health education may have or has had on improving dental health. Although I believe dental health education to be less important to dental health status than the effects of better education, increased affluence, and the increased adoption of middle-class values by society, it has had some effect.

\section{Dietary changes}

Despite improvements in tooth retention statistics, the prevalence of dental caries in teenagers and young adults does not seem to have changed much during the past 50 years. The principal reason, it is suggested, is the profound dietary changes that have occurred during the last 100 years.

It is outside the scope of this paper to delineate in detail the relation between the ingestion of refined carbohydrates, especially sucrose, and the prevalence of dental caries, one of the oldest and least-disputed observations in dentistry. ${ }^{11,15,59,112}$ It has been verified experimentally and uniquely in the Vipeholm study, ${ }^{37}$ demonstrated in the reduced caries prevalence in war-affected countries when refined carbohydrates became unavailable, ${ }^{97}, 100$ as well as in studies of persons with unusual dietary restrictions. ${ }^{41,71}$ There have also been many reports of the distressing consequences which follow the exposure of previously caries-free societies to high-sucrose diets, $8,20,39,50,68,80$ The subject has been analyzed in a number of exhaustive literature reviews. ${ }^{28,40.70,94}$ 
Even in those reports where some of this evidence is criticized, ${ }^{57,94,96}$ it is the strength of the relation rather than the relation itself which is questioned. In summary, the evidence is overwhelming that high-sucrose diets are a major contributory cause in initiating the carious process.

Although total carbohydrate consumption has changed little in nearly 100 years in both Britain ${ }^{49}$ and the United States, ${ }^{4}$ the proportion of total carbohydrate that is sugar has risen appreciably, and the part consisting of starches has decreased. ${ }^{18,86}$ Moreover, the increase in sugar consumption has occurred mainly in processed and manufactured foods rather than in foods cooked from scratch at home, ${ }^{86}$ thereby reducing consumers' choices if they are trying to lower their sugar consumption. For example, during the period from 1909-13,19.3 pounds of refined sugar were consumed per capita by Americans in manufactured food products and beverages. In 1971, the corresponding figure was 70.2 pounds. ${ }^{86}$ The attractiveness of sugar as an additive to manufactured foods is not limited to producing a sweet taste, for it also provides body, plasticity, luster, gloss, and it aids emulsification. ${ }^{2,81}$ The result is that sugar can now be found in an extraordinary variety of processed foods in which one would normally not expect it to be found. ${ }^{93}$

Figure 4 shows the rise in sugar consumption in the United States, the United Kingdom, and the world, from the late 1800s to the present time. ${ }^{4,18,101,102}$ This figure depicts only the consumption of sucrose; it does not show the increase in consumption of sugar substitutes, largely corn syrups, since the abrupt rise of world sugar prices

FIGURE 4

TRENDS IN SUGAR CONSUMPTION IN U.K., U.S.A, AND WORLD, FROM 1880.

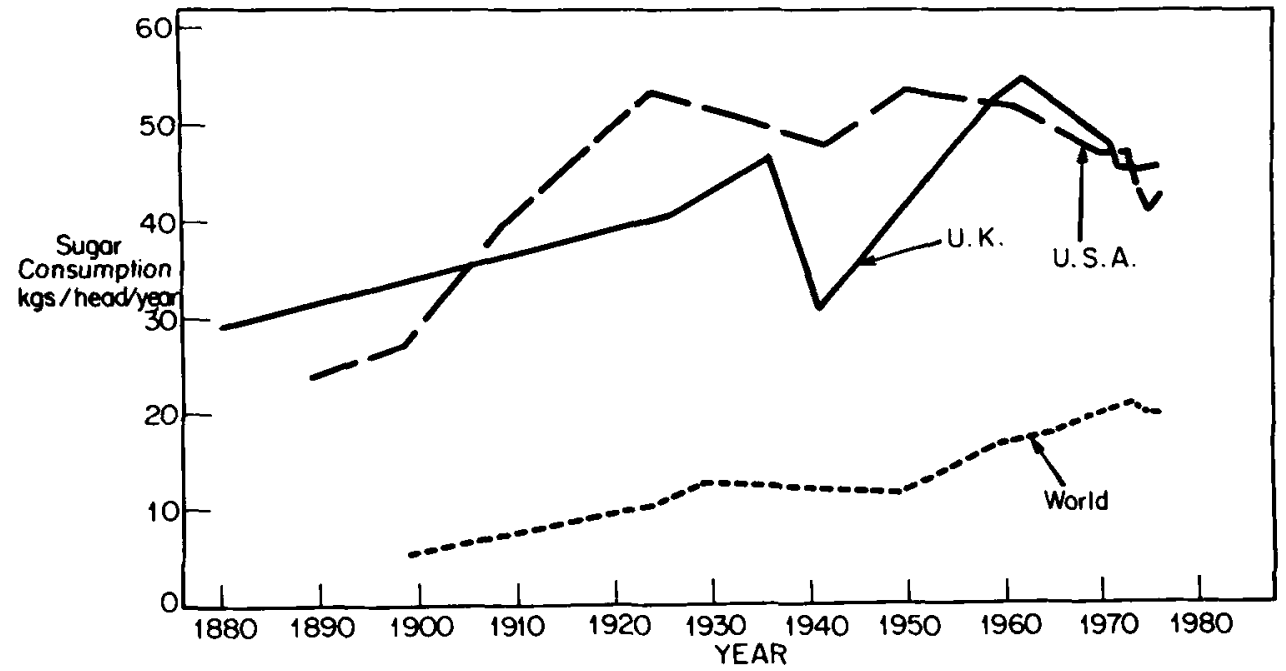

in 1974.101 The apparent drop in sugar consumption in recent years does not mean that people are losing their taste for sweets; consumption of sweeteners is not diminishing in America. Between 1970 and 1976 average per capita consumption of sweeteners in the United States increased from 57.4 to $60.2 \mathrm{~kg}$. per year. During this period, consumption of sucrose decreased from 46.2 to $43 \mathrm{~kg}$., while use of corn syrup and dextrose increased from 8.4 to $13.6 \mathrm{~kg}$. Noncaloric sweeteners increased 
from 2.8 to $3.6 \mathrm{~kg} .{ }^{102}$ Whether this trend will continue or if it proves beneficial to dental health is not known.

Perhaps the most disturbing feature of Figure 4 is the steady rise in world consumption of sugar. The apparent leveling-off of consumption in the USA and Britain is reported to be occurring elsewhere in high sugar-consuming societies, indicating that sugar-consumption in many developing countries is rising rapidly. ${ }^{82}$ It is in these same parts of the world that the prevalence of dental caries is showing an ominous increase as well. ${ }^{10}$ The link between dietary consumption of sugar and prevalence of caries in a population is clear and extraordinarily consistent.

In the United States, the Select Committee on Nutrition and Human Needs has set national dietary goals, ${ }^{86}$ as shown in Figure 5 . The principal desired change is a reduction in consumption of saturated fats, and it may at first seem surprising

FIGURE 5

DIETARY GOALS FOR THE UNITED STATES, 1977

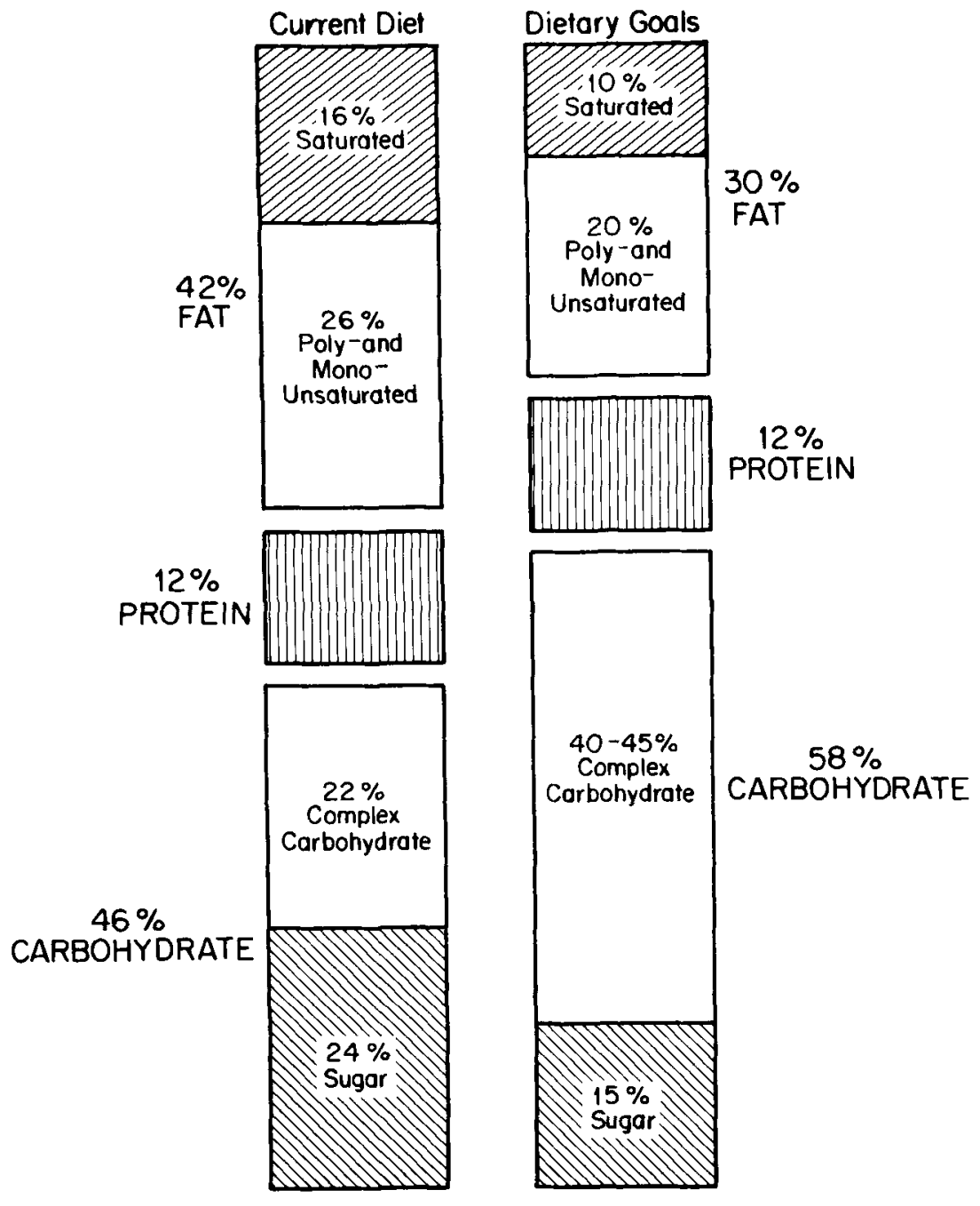


that an actual increase in carbohydrate consumption is suggested. However, note the suggested change in the nature of the carbohydrates consumed; while caloric intake from carbohydrates is advised to increase from the present 46 percent to 58 percent, sugar's share of this caloric intake is recommended to drop from the present 24 percent to 15 percent ${ }^{86}$ If these goals can be achieved in the United States, a reduction in future caries prevalence is possible, along with other important improvements in health status. Progress in other countries, such as Norway, which has now adopted a national food policy, ${ }^{87}$ will be watched with interest.

\section{Man's adaptation to disease}

Rene Dubos has suggested that health status is a result of man's adaptive efforts to reach a state of equilibrium with his environment, and that, for man's well-being, stress is necessary to achieve this adaptation. ${ }^{23,24}$ Dubos uses the word "environment" in its broadest sense, comprising physical, microbiological, social, spiritual, and cultural factors. He postulates further that when the environment is in a state of rapid change, man's efforts to adapt are difficult, and that disease results. If this ecological view of disease is accepted, it may be that the rapid changes that took place in the physical environment of the 19th century were matched by abrupt changes in the intraoral microbiological environment, which was compounded by changes in dietary practices. The epidemic of dental caries during the last 100 years may have been the outcome. If the reduction in caries prevalence observed among children in some industrialized countries in recent years is real, could it, in part, be because of the development of some herd-resistance to dental caries, i.e., a form of adaptation to the conditions that cause the onset of the disease?

Not all immunologists are likely to accept this suggestion. They might point out that this hypothesis may be valid for diseases of specific bacterial origin, such as tuberculosis, but that it is unlikely to apply to caries, in which a number of bacteria are thought to play a causative role. However, we are barely beginning to understand the ecology of disease. I leave you with the thought that it is possible that some natural resistance to caries may now be appearing in those populations in which a high prevalence of the disease has been present for 100 years or more.

By contrast, caries prevalence is now increasing rapidly in many developing countries in which the disease was virtually unknown a short time ago. ${ }^{10}$ From an historical perspective, it is possible that people in these developing countries may be in the same situation as that of the populations of the industrialized countries in the mid1800 s i.e., not having had an opportunity to develop resistance to caries and exposed to a rapid change in the intraoral environment induced by dietary change. If the ecological hypothesis is correct, it means that these societies may experience a long period of high prevalence of caries before they begin to show some effects of adaptation to the disease.

\section{Summary and conclusions}

During the last 100 years there has been a marked reduction in oral sepsis and gross dental pathology, although this type of improvement does not show up in commonly used dental indices. Within the limitations of available data on tooth mortality, the following conclusions are suggested:

1. Tooth retention in ind ustrialized nations has increased during the last 50-100 years, although the improvement has not been large, and has even included a period from 
the early 1920's to around 1940 when it may have declined. The mass extraction of teeth as alleged foci of infections is still influencing national data on dental health at present.

2. The reasons for the improvement in tooth retention among younger persons are related to:

a) better education and affluence, and a more general adoption of middle-class values by the public, resulting in increased use of dental services, and more positive attitudes toward dental health.

b) marked alteration in the philosophy of dental treatment, away from mass extractions and discouragement of treatment for children to a preventive approach which emphasizes tooth retention, and in which early preventive care for children is considered fundamentally important.

c) in recent years, the combined effects of water fluoridation, fluoride tablets, topical fluoride applications, fluoride dentifrices, and perhaps even traditional programs of dental health education.

However, the impact of these factors on tooth retention in older persons is less certain.

3. It is difficult to relate the supply of dental manpower to tooth retention data; it appears to be more important what the providers do than how many there are. However, given the more preventive approach of dentists in recent years, allied with improvements in public education, affluence, and access to dental care, it is likely that an increased supply of dental manpower may be related positively to improved tooth retention in time.

4. The prevalence of dental caries has not declined during the last 50 years, although there may be the beginnings of a downward trend in recent years. As yet, it is too early to tell if these recent data represent a real change in caries prevalence.

5. A principal reason for the lack of a reduced prevalence of dental caries is the dietary practices of western societies, chiefly the high consumption of sugar. The increasing consumption of sugar in many developing countries is a matter of grave concern.

6. If the apparent reduction in caries seen in recent years is real, it is possible that man may be adapting to the pathogenic bacteria which cause the disease. It is hypothesized that as man has adapted to other pathogens and increased his immunity to them, the same process might occur in relation to dental caries.

\section{References}

1. Ainsworth, N. J. Mottled teeth, Brit. Dent. J., 55:233-50, 274-6, Sept. 1, 1933.

2. Allen, R. J. L., and Brook, M. Carbohydrates and the United Kingdom food manufacturer. Am. J. Clin. Nutrit., 20:163-7, Feb. 1967.

3. American Dental Association, Public Education Program. Do you believe in private practice? Chicago, The Association, c1976. 12 p. (p. 4)

4. Antar, M. A., Ohlson, Margaret A., and Hodges, R. E. Changes in retail market food supplies in the United States in the last seventy years in relation to the incidence of coronary heart disease, with special reference to dietary carbohydrates and essential fatty acids. Am. J. Clin. Nutrit., 14;169-78, Mar. 1964

5. Baerum, Per. Dental Director, Health Services of Norway. Personal communication, Feb. 8, 1978.

6. Banta, David. What is health care? p. 12-39. (In Jones, Steven, ed. Health care delivery in the United States. New York, Springer, 1977. xviii +492 p.)

7. Barmes, D. E. Features of oral health care across cultures. Internat. Dent. J., 26:353-66, Sept. 1976.

8. Baume, L. J. Caries prevalence and caries intensity among 12,344 school children of French Polynesia. Arch. Oral Biol., 14:181-205, Feb. 1969.

9. Beck, D. J. Dental health status of the New Zealand population in late adolescence and young adult- 
hood. Department of Health Special Report Series no. 29. Wellington, National Health Statistics Centre, 1968. 106 p. (p. 44)

10. Bibby, B. G. Inference from natural occurring variations in caries prevalence. J. Dent. Res., 49:11941200, Nov.-Dec. 1970.

11. Breese, F. Diet and teeth. Brit. Dent. J., 56:120-4, Feb. 1, 1934.

12. Brekhus, P. J. A report on dental caries in 10,445 university students (1928-1930). Am. Dent. A. J, 18:1350-6, July 1931 .

13. A second census of dental conditions in the University of Minnesota freshman students. Am. Dent. A. J., 28:1126-9, July 1941.

14. Brothwell, D. R. Teeth in earlier human populations. Proc. Nutrit. Soc., 18:59-65 July 1959.

15. Bunting, R. W. Diet and dental caries. Am. Dent. A. J., 22:114-22, Jan. 1935.

16. Burgess, W. C., and Beck, D. J. Survey of denture wearers in New Zealand, 1968. N. Z. Dent. J., 65:223-32, Oct. 1969.

17. Burt, B. A. The administration of public dental treatment programmes. p. 113-33. (In Slack, G. L., and Burt, B. A., eds. Dental public health; an introduction to community dentistry. Bristol, Wright, 1974. ix +338 p.)

18. Cantor, S. M. Patterns of use. p. 19-29. (In National Academy of Sciences. Sweeteners; issues and uncertainties. Academy forum, fourth of a series. Washington, National Academy of Sciences, 1975. vii + 260 p.)

19. Corbett, M. E., and Moore, W. J. Distribution of dental caries in ancient British populations. IV. The 19th century. Caries Res., 10:401-14, 1976.

20. Curzon, M. E., and Curzon, J. A. Dental caries in Eskimo children of the Keewatin District in the Northwest Territories. J. Canad. Dent. A., 36:342-5, Sept. 1970.

21. Dean, H. T. Endemic fluorosis and its relation to dental caries. Pub. Health Rep., 53:1443-52, 1938.

22. Denby, G. C., and Hollis, M. J. The effect of fluoridation on a dental public health programme. N.Z. Dent. J., 62:32-6, Jan. 1966.

23. Dubos, Rene. Mirage of health. New York, Doubleday, c1959, 230 p.

24. Man adapting. New Haven, Yale University Press, c1965. xxii +527 p.

25. Easlick, K. A., et al. An evaluation of the effect of dental foci of infection on health. Am. Dent. A. J., 42:609-97, June 1951. (p. 612-18)

26. Federation Dentaire Internationale, Basic Facts Sheets. London, Federation Dentaire Internationale, 1974. n.p.

27. Finn, S. B. Prevalence of dental caries. p. 117-73. (In National Research Council, Committee on Dental Health. A survey of the literature of dental caries. Washington, National Academy SciencesNational Research Council, Publ. no. 225, 1952. ix + 567 p.)

28. Finn, S. B., and Glass, R. B. Sugar and dental decay. World Review Nutrit. Dietetics, 22:304-26, 1975.

29. Fisher, William. Compulsory attention to the teeth of schoolchildren. Brit. Dent. J., 6:585-93, Oct. 15, 1885.

30. Fones, A. C. Oral hygiene in relation to public health. Dent. Cosmos, 52:516-24, Apr. 1920.

31. Frazier, P. Jean, Jenny, Joanna, Ostman, Ron, and Frenick, Charles. Quality of information in mass media: a barrier to the dental health education of the public. J. Pub. Health Dent., 34:244-57, Fall 1974.

32. Frazier, P. Jean. The effectiveness and practicality of current dental health education programs from a public health perspective; a conceptual appraisal. Paper presented at the annual meeting of the American Public Health Association, Miami Beach, Florida, Oct. 20, 1976.

33. Fuchs, V. R. Who shall live? Health, economics, and social choice. New York, Basic Books, c1974. vii $+168 \mathrm{p}$.

34. Gift, Helen $\mathrm{C}$. The role of the practicing dentist in the delivery of caries prevention. Final analytical report for contract N01-DE-32423, National Institute of Dental Research. Chicago, American Dental Association, $1975,250 \mathrm{p}$.

35. Glass, R. L., Chiang, T. P., and Fleish, Sylvia. Secular trends in the prevalence of caries. J. Pub. Health Dent., 33:206-10, Fall 1973.

36. Gray, P. G., Todd, J. E., Slack, G. L., and Bulman, J. S. Adult dental health in England and Wales 1968. London, Her Majesty's Stationery Office, 1970. vi + 294 p.

37. Gustafsson, B. E., Quensel, C. E., Lanke, L. S., Lundquist, C., Grahnen, H., Bonow, B. E., and Krasse, B. The Vipeholm dental caries study. The effect of different levels of carbohydrate intake on caries activity in 436 individuals observed for five years. Acta Odont. Scand., 11:232-364, Sept. 1954.

38. Hardwick, J. L. The incidence and distribution of caries throughout the ages in relation to the Englishman's diet. Brit. Dent. J., 108:9-17, Jan. 5, 1960.

39. Hargreaves, J. A. Changes in diet and dental health of children living in the Scottish island of Lewis. Caries Res., 6;335-76, 1972.

40. Hartles, R. L. Carbohydrate consumption and dental caries. Am. J. Clin. Nutrit., 20:152-6, Feb. 1967. 
41. Harris, R. Biology of the children of Hopewood House, Bowral, Australia. 4. Observations on dental caries experience extending over five years (1957-1961). J. Dent. Res., 42:1387-99, Nov. - Dec. 1963.

42. Harris, S. D. ASDC-A renaissance in dental effort. J. Dent. Child., 34:482-3, Nov. - Dec. 1977.

43. Healey, H. J., and Cheyne, V. D. Comparison of caries prevalence between freshman students in two midwestern universities. Am. Dent. A. J., 30:692-700, May 1, 1943.

44. Heifetz, S. B., and Suomi, J. D. The control of dental caries and periodontal disease; a fundamental approach. J. Pub. Health Dent., 33:2-6, Winter 1973.

45. Heifetz, S. B., Bagramian, R. A., Suomi, J. D., and Segreto, V. A. Programs for the mass control of plaque; and appraisal. J. Pub. Health Dent., 33:91-5, Spring 1973.

46. Heilbroner, R. L. The economic problem. Englewood Cliffs, N. J., Prentice Hall, c 1968. xx +652 p.

47. Hewat, R. E. T., and Eastcott, D. F. Dental caries in New Zealand. Christchurch, N. Z., Med. Res. Council N. Z., n.d. 134 p.

48. Hollander, Franklin, and Dunning, J. M. A study by age and sex of the incidence of dental caries in over 12,000 persons. J. Dent. Res., 18:43-60, Feb. 1939.

49. Hollingsworth, Dorothy F., and Greaves, J. P. Consumption of carbohydrates in the United Kingdom. Am. J. Clin. Nutrit, 20:65-72, Feb. 1967.

50. Holloway, P. J., James, P. M. C., and Slack, G. L. Dental disease in Tristan da Cunha. Brit. Dent. J., 115:19-25, July 2, 1963.

51. Holloway, P. J. The success of restorative dentistry? Internat. Dent. J., 25:26-30, Mar. 1975.

52. Horowitz, Alice M., Suomi, J. D., Peterson, J. K., Vogelsong, R. H., and Mathews, Barbara L. Effects of supervised daily dental plaque removal by children: first-year results. J. Pub. Health Dent., 36:193200, Summer 1976.

53. Horowitz, H. S. The arch criminal is still at large. Edit. J. Pub. Health Dent., 37:301-4, Fall 1977.

54. Hyatt, T. P. Report of an examination made of two thousand one hundred and one high school pupils. Dent. Cosmos, 52:507-11, Apr. 1920.

55. Prophylactic odontotomy Dent. Cosmos, 65:234-41, Mar. 1923.

56. Illich, Ivan. Medical Nemesis; the expropriation of health. New York, Bantam, c/1976. xviii $+300 p$.

57. Jackson, D. Caries experience in English children and young adults during the years 1947-1972. Brit. Dent. J., 137:91-8, Aug. 1974.

58. James, P. M. C., Parfitt, G. J., and Roydhouse, R. H. Caries experience during a decade. J. Dent. Child., 37:289-95, July - Aug. 1970.

59. Jay, Philip. The role of sugar in the etiology of dental caries. Am. Dent. A. J., 27:393-6, Mar. 1940.

60. Jenny, Joanna. Alternative models for improving dental health status. Dent. Hyg., 51:503-10, Nov. 1977.

61. Kadushin, Charles. Social class and the experience of ill health. Sociological Inquiry, 34:67-80, Winter 1964.

62. King, J. D., Mellanby, May, Stones, H. H., and Green, H. N. The effect of sugar supplements on dental caries in children. MRC Special Report Series no. 288. London, Her Majesty's Stationery Office, 1955. viii +55 p.

63. Klein, Henry, Palmer, C. E., and Knutson, J. W. Studies on dental caries: I. Dental status and dental needs of elementary school children. Pub. Health Rep., 53:751-65, May 13, 1938.

64. Klein, Henry, and Palmer, C. E. On the epidemiology of dental caries. p. 1-25. (In Klein, Henry, Palmer, C. E., Bibby, B. G., and McCollum, E. V. Dental caries; University of Pennsylvania Bicentennial Conference. Philadelphia, Univ. Pennsylvania Press, 1941. 53 p.)

65. Knutson, J. W., and Klein, Henry. Studies on dental caries. IV. Tooth mortality in elementary school children. Pub. Health Rep., 53:1021-32, June 24, 1938.

66. Logan, R. K. Director, Division of Dental Health, New Zealand Department of Health. Personal communication, July $12,1976$.

67. Ludwig, T. G. The Hastings Fluoridation Project: V: Dental effects between 1954 and 1964. N. Z. Dent. J., 61:175-9, July 1965.

68. McGregor, A. B. Changing diet and its effect on caries prevalence in Ghana. Abstr. J. Dent. Res., 42:1086-7, Sept. - Oct. 1963.

69. McKeown, Thomas. A historical appraisal of the medical task. p. 29-50. (In McLachlan, Gordon, and McKeown, Thomas, eds. Medical history and medical care; a symposium of perspectives. London, Nuffield Provincial Hospitals Trust and Oxford Univ. Press, 1971. xii +244 p.)

70. Makinen, K. K. The role of sucrose and other sugars in the development of dental caries: a review. Internat. Dent. J., 22:363-86, Sept. 1972.

71. Marthaler, T. M., and Froesch, E. R. Hereditary fructose intolerance; dental status of eight patients. Brit. Dent. J., 123:597-9, Dec. 19, 1967.

72. Medical Research Council. Reports of the committee for the investigation of dental disease. II. The incidence of dental disease in children. London, Her Majesty's Stationery Office, 1925. iv $+48 \mathrm{p}$.

73. Medical Research Council, Committee upon Dental Disease. The influence of diet on caries in children's teeth; interim report. MRC Special Report Series no. 159. London, Her Majesty's Station- 
ery Office, 1931. $19+\mathrm{x} \mathrm{p}$.

74. Medical Research Council, Committee for the Investigation of Dental Disease. The influence of diet on caries in children's teeth; final report. MRC Special Report Series no. 211. London, Her Majesty's Stationery Office, 1936. $137+$ xii p.

75. Mellanby, May, and Coumoulos, Helen. The improved dentition of five-year old London schoolchildren. Brit. Med. J., 1:837-40, June 24, 1944.

76. Mellanby, Helen, and Mellanby, May. Dental structure and caries in five-year-old children attending London County Council schools; result of five surveys (1929-49). Brit. Med. J., 1:1341-3, June 10, 1950.

77. Messner, C. T., Gafafer, W. M. Cady, F. C., and Dean, H. T. Dental survey of school children, ages 6-14 years, made in 1933-34 in 26 states. USPHS Bulletin No. 226. Washington, Government Printing Office, 1936, vi $+248 \mathrm{p}$.

78. Miller, R. K. A preliminary survey of the incidence of dental caries in Great Britain. Brit. Dent. J., 74:286-9, June 4, 1943.

79. Ministry of Health. On the state of the public health; the annual report of the Chief Medical Officer of the Ministry of Health, 1964. London, Her Majesty's Stationery Office, 1965. iv + 246 p.

80. Möller, I. J., Poulsen, S., and Nielsen, V. O. The prevalence of dental caries in Godhavn and Scoresbysund districts, Greenland. Scand. J. Dent. Res., 80:169-80, 1972.

81. Newbrun, Ernest. The role of food manufacturers in the dietary control of caries. Am. Soc. Preven. Dent. J., 4:33-44, Sept.-Oct. 1974.

82. Pekkarinen, M. World food consumption patterns. p. 16-33. (In Rechcigal, Miloslav, ed. Man, food, and nutrition. Cleveland, CRC Press, c1973.

83. Pickerill, H. P. The prevention of dental caries and oral sepsis. 3rd. ed, London, Bailliere, Tindall and Cox, 1923. $x i+340$ p.

84. Rayner, Jeannette F, and Cohen, Lois K. School dental health education. p. 275-307. (In Richards, N. D., and Cohen, Lois K., eds. Social sciences and dentistry: a critical bibliography. The Hague, Sijthoff, c1971. 381 p.)

85. Renson, C. E. The administration of dental services: the example of Great Britain. p. 134-59. (In Slack, G. L., and Burt, B. A., eds. Dental public health; an introduction to community dentistry. Bristol, England, Wright, 1974 ix +338 p.)

86. Report of the Select Committee on Nutrition and Human Needs, U. S. Senate. Eating in America; dietary goals for the United States. Cambridge, Mass., MIT Press, 1977. 79 p.

87. Ringen, Knut. The Norwegian food and nutritional policy. Am. J. Pub. Health, 67:550-1, June 1977.

88. Roder, D. M. and Burt, B. A. Evaluation of dental health education in a school dental care program. J. Pub. Health Dent., 38:44-57, Winter 1978.

89. Rogers, D. E., and Blendon, R. J. The changing American health scene; sometimes things get better. Am. Med. A. J., 237:1710-4, Apr. 18, 1977.

90. Rosenstock, I. M. Why people use health services. Milbank Mem. Fund Quar., 44:94-124, (part 2), July 1966.

91. Russell, A. L. World epidemiology and oral health. p. 21-39. (In Kreshover, S. J., and McClure, F. J., eds. Environmental variables in oral disease. Washington, American Association Advancement Science, Publ. No. 81, 1966. xii +311 p.)

92. Schiötz, E. H. Dental caries and nutrition: investigations of children from Norwegian elementary schools and infant homes. Brit. Dent. J., 66:57-67, Jan. 16, 1939.

93. Shannon, I. L. Sucrose-the tooth's mortal enemy; fluoride-the tooth's best friend. J. Dent. Child., 44:429-37, Nov. - Dec. 1977.

94. Shaw, J. H. Nutrition and dental caries. p. 415-567. (In National Research Council, Committee on Dental Health. Survey of the literature on dental caries. Washington, Nat. Acad. Sciences-Nat. Res. Council, Publ, 225, 1952. ix +567 p.)

95. Sheiham, A. An evaluation of the success of dental care in the United Kingdom. Brit. Dent. J., 135-271-9, Sept. 18, 1973.

96. Sognnaes, R. F. Analysis of wartime reduction of dental caries in European children. Am. J. Dis. Child., 75:792-821, June 1948.

97. Takeuchi, M. Epidemiological study on dental caries in Japanese children, before, during and after World War II. Internat. Dent. J., 11:443-57, Dec. 1961.

98. Todd, Jean E. Children's dental health in England and Wales 1973. London, Her Majesty's Stationery Office, 1975. vi $+387 \mathrm{p}$.

99. Todd, Jean E., and Whitworth, A. Adult dental health in Scotland, 1972. London, Her Majesty's Stationery Office, 1974. viii +257 p.

100. Toverud, Guttorm. The influence of war and post-war conditions on the teeth of Norwegian school children. III. Discussion of food supply and dental condition in Norway and other European countries. Milbank Mem. Fund Quar., 35:373-459, Oct. 1957.

101. United Nations, Food and Agriculture Organization. The state of food and agriculture, 1976. FAO 
agriculture series no. 4. Geneva, UNO, 1977. vi +157 p.

102. U. S. Department of Agriculture. Economics, Statistics, and Cooperative Service. Personal communication, Feb. 10, 1978.

103. U. S. Department of Commerce, Bureau of the Census, Statistical abstract of the United States, 1975. 96th ed., Washington, Government Printing Office, 1975. xx $+1050 \mathrm{p}$.

104. U. S. Public Health Service, National Center for Health Statistics. Decayed, missing, and filled teeth in adults, United States-1960 - 1962, by Kelly, J. E., van Kirk, L. E., and Garst, Caroline C. PHS Publ. No. 1000-Ser. 11-No. 23, Washington, Government Printing Office, 1967. 47 p.

105. Decayed, missing, and filled teeth among children, United States, by Kelly, J. E., and Scanlon, J. V. DHEW Publ. No. (HSM) 72-1003 Ser. 11-No. 106. Washington, Government Printing Office, $1971.47 \mathrm{p}$.

106. . Dental visits; volume and interval since last visit, United States-1969, By Wilder, C. S. DHEW Publ. No. (HSM) 72-1066-Ser. 10 No. 76. Washington, Government Printing Office, 1972. 37. $\mathrm{p}$.

107. Decayed, missing, and filled teeth among youths 12-17 years, United States, by Kelly, J. E., and Harvey, Clair R. DHEW Publ. No. (HRA) 75-1626-Ser. 11 - No. 144. Washington, Government Printing Office, 1974, iii +34 p.

108. . Edentulous persons, United States-1971, by Burnham, C. E. DHEW Publ. No. (HRA) 74-1516-Ser. 10-No. 89. Washington, Government Printing Office, 1974. iv + 31 p.

109. Current estimates from the Health Interview Survey, United States-1975, by Drury, T. F. DHEW Publ. no. (HRA) 77-1543-Ser. 10-No. 115. Washington, Government Printing Office, 1977. iv $+74 \mathrm{p}$.

110. U. S. Public Health Service, Center for Disease Control. Fluoridation census 1975. Atlanta, Government Printing Office, 1977. iv +407 p.

111. Waerhaug, Jens. Epidemiology of periodontal disease-review of literature. p. 181-211. (In Ramfjord, S. P., Kerr, D. A., and Ash, M. M. eds. World workshop in periodontics. Ann Arbor, University of Michigan, c1966. xx +458 p. (p. 191-2)

112. Wallace, J. S. The cause and prevention of decay in teeth. 2nd ed. London, Churchill, 1902. 108 p.

113. Wheatley, James. Prevention of dental caries and the desirability of government investigation. Brit. Dent. J., 41:753-68, Aug. 16, 1920.

114. Williams, R. M., Jr. The structure of American society; a sociological interpretation. New York, Knopf, 1959. xiii $+545+$ xi p.

115. Yudkin, John. Evolutionary and historical changes in dietary carbohydrates. Am. J. Clin. Nutrit., 20:108-15, Feb. 1967. 